\title{
The Effect of Application of The Brain-Based Learning (BBL) Approach on The Connection Ability of Students
}

\author{
Anisa Fitri ${ }^{1}$, Ahmad Zaeni² \\ 1 SMK Budi Tresna Muhammadiyah Cirebon \\ 2 Universitas Negeri Jakarta \\ Waruroyom,, Depok, Cirebon,45653 Indonesia, zaeni115@gmail.com
}

\author{
a r t i c l e i n f o \\ How to cite this article: \\ Fitri, A., \& Zaeni, A. (2020). The Effect of \\ Application of The Brain-Based Learning (BBL) \\ Approach on The Connection Ability of Students. \\ Eduma : Mathematics Education Learning And \\ Teaching, 9(2), 66 - 78. doi: \\ http://dx.doi.org/10.24235/eduma.v9i2.7373
}

Article history:

Received: 11 17, 2020

Accepted: 11 30, 2020

Published: 12, 2020

\section{Copyright (C) 2020}

EduMa: Mathematics Education Learning and Teaching under the Creative Commons Attribution 4.0 International License.

\section{a b s t r a c t}

THE EFFECT OF APPLICATION OF THE BRAIN-BASED LEARNING (BBL) APPROACH ON THE CONNECTION ABILITY OF STUDENTS. This research is based on the low ability of students' mathematical connections. A learning approach that can improve students' mathematical connection ability is the BrainBased Learning (BBL) approach. The purpose of this study is to determine whether there is influence from the application of the Brain-Based Learning (BBL) approach to students' mathematical connection ability. The method used in this research is quantitative research (experimental study) with One-Shot Case Study Design research design. This study's sample is the students of class X.MIPA. 4 consisting of 28 students obtained by simple cluster random sampling technique. The instrument used in this research is using the questionnaire and test. The data analysis technique used is the linear regression test. From a hypothesis test, $t$-count $>t$-table is 4,003> 1,710, then $\mathrm{H} 0$ is rejected, and Ha accepted. So it can be concluded that there is a positive influence of applying the BrainBased Learning (BBL) approach to students' mathematical connection ability with a considerable influence equal to $37.5 \%$.

Ke y words :

Brain-Based Learning Approach (BBL), Ability of Mathematical Connection

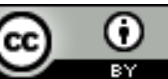




\section{INTRODUCTION}

The teacher plays an important role in the learning process because it is responsible for encouraging, guiding, and providing learning facilities for students to obtain learning outcomes following expectations (Supriadie \& Darmawan, 2012; Saragih, 2008)

This is far from being expected, based on the fact that students still have difficulty understanding mathematics. The factors that cause difficulties based on the analysis of student answers are that students are not capable of mastering concepts, a combination of concepts, and skills in completing (Rumasoreng \& Sugiman, 2014; Jamal, 2019).

One solution to this problem is learning using the Brain-Based Learning approach because in $\mathrm{BBL}$, learning mathematics provides opportunities for students to hone thinking skills, especially mathematical thinking skills, including high-level mathematical thinking skills.

This means that there is a learning process in the education system that involves teachers as educators and students as students, which are commonly referred to as teaching and learning activities.

Romberg (2016) states several aspects of higher thinking, namely mathematical problem solving, mathematical communication, mathematical reasoning, and mathematical connections. Thus, learning using the Brain-Based Learning (BBL) approach in mathematics learning provides students opportunities to hone their mathematical connection skills.

Learning is an activity or effort made by the teacher so that students learn. Teachers play an important role in the learning process because they are tasked with encouraging, guiding, and providing learning facilities for students to obtain learning outcomes that are in line with expectations (Supriadie \& Darmawan, 2012; Saragih, 2008).

The ability to connect mathematics is one component of the basic skills that students must have in learning mathematics. Linto et al. (2012) say that the ability to connect mathematics is the ability to relate mathematical concepts to one another, with other fields of study, or with applications in the real world.

Based on the observations that researchers have done, many students think that learning mathematics is difficult, even though mathematics is one of the most important sciences to learn because it is related to everyday life. According to Hendriana \& Soemarmo (2014), everyone in their life activities will be involved with mathematics, starting from simple and routine forms to complex ones. These activities include counting and counting, two examples of routine and simple math activities, almost done by everyone.

Therefore, students' ability to make mathematical connections itself is very important for conceptual understanding (Anthony \& Walshaw, 2009).

This is in line with the objectives of learning mathematics in schools according to the 2006 Ministry of National Education are: (1) understand mathematical concepts, explain the relationship between concepts and apply concepts or algorithms, in a flexible, accurate, efficient and precise manner, in problem solving, (2) use reasoning on patterns and properties, perform mathematical manipulation in 
making generalizations, compile evidence, or explain mathematical ideas and statements, (3) solve problems which include the ability to understand problems, mathematical design models, solve models, and interpret the solutions obtained, (4) communicating ideas with symbols, tables, diagrams or other media to clarify situations or problems, and (5) having an attitude of appreciating the usefulness of mathematics in life, namely having curiosity, attention, and interest in learning mathematics, as well as being resilient. Confident in solving problems "(Depdiknas, 2006).

This is following what is formulated by NCTM (in Anandita, 2015) regarding the standard abilities students must have in learning mathematics, namely problem solving skills, reasoning skills, communication skills, and the ability to make connections (connection), and representation capabilities.

The ability to connect mathematics is one component of the basic skills that students must have in learning mathematics. The ability to connect mathematics is the ability to relate mathematical concepts to one another, with other fields of study, or with applications in the real world (Linto et al., 2012).

Prior to the research, researchers interviewed on November 29, 2016, regarding the students' mathematical connection ability. The information obtained from the interview results shows that students are less enthusiastic about learning mathematics because they still think mathematics is complicated. The teacher acknowledged that the lecture method's learning was still dominated by giving questions and working on students' practice questions. The result is that students will find it difficult to face application questions or questions that are different from those exemplified by the teacher. Students' ability to connect mathematics is still low; there are still many students who lack confidence in their abilities; they prefer to cheat rather than do it themselves according to their abilities.

To improve students' mathematical connection skills, a good thinking ability is needed. Therefore, in the learning process, the teacher must use a learning approach that can develop students' ideas and ideas to improve their mathematical connection skills. Teachers should pay attention to one important thing in the human body whose abilities have been under-optimized, namely the brain. This is because in teaching mathematical connection skills, it is necessary to balance the right brain and left brain so that learning becomes more effective.

Effective learning is effective learning that can balance the potential of students' right brain and left brain. If education in the classroom does not involve these two brain functions, there will be a cognitive imbalance in students, namely the potential for one part of the brain to be weakened due to not using the function of that part of the brain (Lestari, 2014). Therefore, we need a learning approach that can optimize the brain's work and improve students' mathematical connection skills, namely a brain-based learning approach.

Learning using the Brain-Based Learning approach in learning mathematics provides opportunities for students to hone thinking skills, especially mathematical thinking skills, including high-level mathematical thinking skills. This is following what was said by Istianah (2013), that learning mathematics must provide 
opportunities to learn to think mathematically.

Based on the explanation above, it is hoped that applying the Brain-Based Learning (BBL) approach can improve students' mathematical connection skills. Therefore, researchers are interested in researching "The Effect of the Application of BrainBased Learning (BBL) Approach on Students' Mathematical Connection Ability."

The formulations of the problems to be assessed in this research are (1) How do students respond to the application of the Brain-Based Learning (BBL) approach (2) How are the students' mathematical connection skills after applying the Brain Based Learning (BBL) approach (3) Is there an effect of the application of the Brain Based Learning approach on the mathematical connection ability?.

\section{LITERATURE REVIEW}

\section{The BBL approach}

The Brain-Based Learning (BBL) approach can be interpreted as a brain-based learning approach. Brain-Based Learning (BBL) (Jensen, 2008) is learning that is aligned with how the brain is naturally designed to learn with seven design learning stages, namely: pre-exposure, preparation, initiation and acquisition, elaboration, incubation, and memory entry, levers. , Grace and Integration. In line with this, Sapa'at (in Yulvinamaesari, 2014) states that Brain-Based Learning is learning based on the structure and workings of the brain, so that the work of the brain can be optimal.

According to Awolola (Al'Azzy \& Budiono, 2008), Brain-Based Learning (BBL) is student-centered learning, and the teacher as a facilitator plays a role in supporting student cognition. This means that the Brain-Based Learning (BBL) approach is written to the student center. Three main strategies can be developed in the application of the Brain-Based Learning (BBL) approach, namely: creating a learning environment that challenges students' thinking abilities, creating a pleasant learning environment, creating active and achieving learning situations for students (Zarkasyi, 2015).

There are seven stages in the implementation of the Brain-Based Learning (BBL) approach proposed by Jensen in his book, namely: (Jensen, 2008)

a. Pre-exposure stage

The pre-exposure phase is where you give your brain a review of new learning before it really digs any further. This stage will help the brain build a better conceptual map.

b. Preparation phase

The preparatory stage is the phase in creating curiosity and pleasure

c. Initiation and Acquisition Stage

The initiation and acquisition stages focus on the learning content. This stage is the stage of creating connections or when the neurons "communicate" with each other.

d. Elaboration Stage

The elaboration stage is the processing stage, which is making intellectual impressions about learning. The elaboration stage provides the brain with the opportunity to sort, investigate, analyze, test, and deepen learning

e. Incubation stage and entering memory The incubation and memory entry phases emphasize the importance of rest and repetition times because the brain learns most effectively over time, not immediately over time. At this 
stage, it takes time to relax, to stabilize attention and emotions.

f. Verification and confidence checking stage

The teacher checks whether the students understand the material that has been studied or not. Students also need to know whether they have understood the material or not.

g. Celebration and Integration Stage

The celebration and integration stage is a very important stage, especially for engaging emotions. This stage instills all the significance of a love of learning. The celebration and integration stage is an exciting, cheerful, and fun stage

\section{Mathematical Connection Capability}

According to NCTM (in Rizka, et.al, 2014), mathematical connections can see, use, and make connections between mathematical ideas and contexts outside mathematics to build mathematical understanding. Mathematical connection indicators can link mathematics in the interactions between mathematical topics, connect mathematics with other sciences, and interest in their own experiences.

Mathematical connection ability indicators include: (House and Coxford, 1995)

1) Connecting conceptual and procedural knowledge.

2) Using math in other topics.

3) Using mathematics in life activities.

4) See mathematics as an integrated unit.

5) Applying mathematical thinking skills and making models for solving problems in other subjects, such as music, art, psychology, science, and business.

6) Knowing the connection between the topics in mathematics.

7) Recognizing various representations for the same concept.

\section{METHODS}

In this study, the population of all class academic year was 264 students, and the sample in this study was class, totaling 28 students. The sample was determined by using a simple cluster random sampling technique. Simple Cluster Random Sampling or simple cluster random samples, is a sampling that is carried out on research units or elementary units of the population grouped into clusters called clusters (Nasehuddien \& Manfaat, 2015). A sampling of the groups that will be sampled is carried out randomly, provided that the groups in the population have homogeneous characteristics. As for what is randomized, the class, not the students, the cluster, and random.

The research method used in this research is quantitative research methods (experimental studies). Quantitative research (Hidayah, 2015) is a means of testing the objective theory by examining the relationship between measurable variables.

The research design used in this study is One-Shot Case Study Design. One-Shot Case Study Design (Zarkasyi, 2015) is a study conducted in a given treatment or treatment group, then the results are observed. In this study, the treatment is the independent variable (BBL approach), and the results observed are the dependent variable (Mathematical Connection Ability).

$$
\begin{aligned}
& \mathrm{X} \longrightarrow \mathrm{Y} \\
& \text { Information: } \\
& \mathrm{X}=\text { Brain Based Learning (BBL) } \\
& \text { approach } \\
& \mathrm{Y}=\text { Math connection ability } \\
& \rightarrow=\text { Influence }
\end{aligned}
$$

The data collection techniques used in this study were questionnaires and test 
administration. A questionnaire or questionnaire (Sugiyono, 2013) is a data collection technique that is done by giving a set of questions or written statements to respondents to answer. This questionnaire is used to obtain data on how students respond to mathematics learning by applying the Brain-Based Learning approach.

The questionnaire assessment technique in this study uses a Likert scale which is divided into five scales arranged in stages, starting from "Strongly Agree (SS)", "Agree (S)", "Doubtful (N)", "Disagree (TS). )", And" Strongly Disagree (STS) "or can be arranged otherwise (Siregar, 2010).

The test (Baskoro \& Wihaskoro, 2014) is a series of questions or exercises used to measure skills, knowledge, intelligence, abilities, or talents possessed by individuals or groups. This test aims to obtain data about students' mathematical connection skills after applying the BrainBased Learning (BBL) approach.

\section{Research Design, Site, and Participants}

The time needed in this research starts from the preparation stage to preparing the report, namely for five months from January to May 2017. The research design used in this study is One-Shot Case Study Design. One-Shot Case Study Design (Zarkasyi, 2015)

\begin{tabular}{lcccr}
\hline & N & $\begin{array}{c}\text { Minimu } \\
\mathrm{m}\end{array}$ & $\begin{array}{c}\text { Maximu } \\
\mathrm{m}\end{array}$ & Mean \\
\hline KemampuanKone & 2 & & & 68.557 \\
ksi Mtk & 6 & 47.50 & 87.50 & 7 \\
& 2 & & & \\
Valid N (listwise) & 6 & & & \\
\hline
\end{tabular}

Design is a study conducted in a given treatment group, then the results are observed. Treatment is independent and the outcome is the dependent variable. The paradigm in this study is illustrated as follows. (Zarkasyi, 2015)

\begin{tabular}{c|c}
\hline $\mathrm{X}$ & $\mathrm{O}$ \\
\hline
\end{tabular}

Research design

Information :

$\mathrm{X}=$ Treatment $/$ treatment given (Independent variable / BBL approach)

$\mathrm{O}=$ Postes (Observed dependent variable / mathematical connection ability).

\section{RESULT AND DISCUSSION}

\section{Student Responses to the Application of the Brain-Based Learning (BBL) Approach}

In this study, finding out how many students respond to the application of the Brain Based Learning (BBL) approach was carried out by providing a questionnaire consisting of 7 components (Pre-Exposure, Preparation, Initiation, Elaboration, Incubation, Verification, Celebration and Integration) and 11 indicators. With a total of 22 statement items. The questionnaire was distributed to 26 students in the experimental class.

The data description from the distribution of student response questionnaires to the application of the Brain Based Learning (BBL) approach can be seen in the following table:

Table 1

BBL Approach Statistics

\section{Research Design}

This study uses a One-Shot Case Study Design research design. According to Zarkasyi (2015), One-Shot Case Study
Based on table 1, it is known that the student response to the application of the Brain-Based Learning (BBL) approach with the number of respondents $(\mathrm{N})$ as 
many as 26 students obtained a minimum score of 61 , a maximum score of 82 , and an average score of 75.35 .

The recapitulation of student response questionnaire data to the application of the Brain-Based Learning (BBL) approach based on each indicator can be described in the form of a bar chart as in Figure 1.

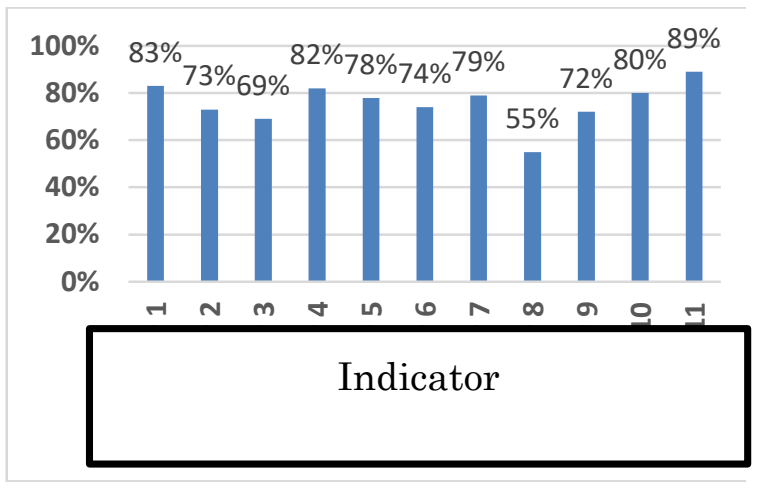

\section{Picture 1 \\ Student Response Diagram}

The bar chart image above shows the percentage of each student response indicator to applying the Brain-Based Learning (BBL) approach. The highest percentage lies in the 11th indicator, which is like learning. Meanwhile, the lowest percentage lies in the 8th indicator, which is having sufficient time to record material.

\section{Students' Connection Ability after applying the BBL Approach}

Students' ability to connect mathematics is obtained from the results of tests carried out when the learning material about trigonometry has been taught, supported by the BBL approach. The test consisted of 8 description questions given to 26 students in the experimental class, namely. The following are the results of calculating the descriptive statistics of the posttest scores obtained by the students

Table 2

Statistics of Students' Mathematical Connection Ability

\begin{tabular}{lcccc}
\hline & N & $\begin{array}{c}\text { Minimu } \\
\mathrm{m}\end{array}$ & Maximum & Mean \\
\hline $\begin{array}{l}\text { Pendekatan } \\
\text { BBL }\end{array}$ & 26 & 61 & 82 & 75.35 \\
$\begin{array}{l}\text { Valid N } \\
\text { (listwise) }\end{array}$ & 26 & & & \\
\hline
\end{tabular}

From Table 2, it can be seen that the minimum score for student test results is 47.50 , and the maximum score obtained by students is 87.50 , and the average value is 68.5577 .

The following is a recapitulation table and a bar chart for the test results based on the percentage of students' math connection ability test results on each of the indicators described.

Table 3

Recapitulation of Students' Mathematical Connection Ability Test Results

\begin{tabular}{lll}
\hline No & indicator & $\begin{array}{l}\text { presenta } \\
\text { tion }\end{array}$ \\
\hline 1 & $\begin{array}{l}\text { using connections between } \\
\text { math topics }\end{array}$ & $68 \%$ \\
2 & $\begin{array}{l}\text { using connections between } \\
\text { math topics with other } \\
\text { sciences }\end{array}$ & \\
& $\begin{array}{l}\text { use mathematics in solving } \\
\text { problems in life }\end{array}$ & $69 \%$ \\
3 & $68,33 \%$ \\
\hline
\end{tabular}

The data above shows that the average percentage of students' ability to use connections between mathematical topics, use connections between mathematics and other sciences, and use mathematics in solving problems related to everyday life is $68 \%$. This can be interpreted that the mathematical connection ability after using the BrainBased Learning (BBL) approach on the subject of trigonometry is in a good category.

The recapitulation of the students' mathematical connection ability test results is then depicted in the form of a bar chart, as shown in Figure 2. 


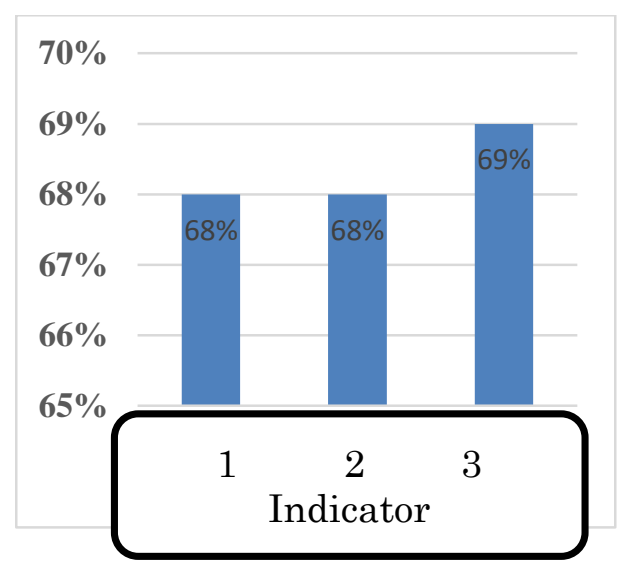

Figure 2 Student Mathematical Connection Ability Diagram

The bar chart above shows the percentage of each indicator of a student's mathematical connection ability after the Brain-Based Learning (BBL) approach is applied. The highest percentage lies in the 3rd indicator, which uses mathematics to solve problems related to everyday life. While the lowest rate does not exist because in the 1st and 2nd indicators, the percentage value is balanced or the same, so it can be said that students' ability to use connections between mathematical topics and use mathematical connections with other sciences is balanced.

a. The data normality test is a test conducted to determine whether the research data is spread normally or not. The normality test in this study used the Shapiro-Wilk test because the sample size was less than 50 people.

Table 4

Test of Normality

\begin{tabular}{llll}
\hline & \multicolumn{3}{l}{ Shapiro - Wilk } \\
& Statistic & df & sig \\
\hline $\begin{array}{l}\text { Unstandarized } \\
\text { Residual }\end{array}$ & .968 & 26 & .577 \\
\hline
\end{tabular}

The homogeneity test is carried out to determine whether the data distributed as a result of the research is homogeneous or not. The results of the homogeneity test using IBM SPSS Statistics 20 can be seen in Table 5
Table 5

Test of Homogeneity of Variances

Mathematical Connection Ability

\begin{tabular}{lccc}
\hline $\begin{array}{l}\text { Levene } \\
\text { Statistic }\end{array}$ & Df1 & Df2 & Sig. \\
\hline 2.451 & 7 & 13 & .077 \\
\hline
\end{tabular}

From Table 5, it is known that the significance value is 0.077 . Because the significance value is $0.077>0.05$, it can be concluded that the research data is homogeneous

Linearity test aims to determine whether the two variables have a linear or not significant relationship. The results of the linearity test using IBM SPSS Statistics 20 can be seen in Table 6.

Table 6

\section{ANOVA Table}

\begin{tabular}{ccccc}
\hline $\begin{array}{c}\text { Sun of } \\
\text { Squares }\end{array}$ & df & $\begin{array}{c}\text { Mean } \\
\text { Sguare }\end{array}$ & $\mathrm{f}$ & sig \\
\hline 3096.955 & 12 & 258.080 & 2.012 & .113 \\
1907.804 & 1 & 1907.804 & 14.872 & .002 \\
1189.151 & 11 & 108.105 & .843 & .607 \\
1667.708 & 13 & 128.285 & & \\
4764.663 & 25 & & & \\
\hline
\end{tabular}

Based on Table 6, it can be seen that the significance value (linearity) is 0.002 because the significant value is 0.002 $<0.05$, it can be concluded that the variables of the Brain-Based Learning (BBL) approach and the mathematical connection ability variable have a linear relationship. 


\begin{tabular}{|c|c|c|c|c|c|}
\hline & B & $\begin{array}{l}\text { Std. } \\
\text { Erro } \\
\mathrm{r}\end{array}$ & Beta & & \\
\hline (Consta & - & 31.5 & & - & .081 \\
\hline nt) & $\begin{array}{l}57.4 \\
51\end{array}$ & 48 & & 1.821 & \\
\hline $\mathrm{X}$ & $\begin{array}{l}1.51 \\
9\end{array}$ & .379 & .633 & 4.003 & .001 \\
\hline
\end{tabular}

The regression equation is as follows:

$$
\begin{aligned}
& \hat{\mathrm{Y}}=\alpha+\mathrm{bX} \\
& \hat{\mathrm{Y}}=-57,451+1,519 \mathrm{X} \\
& \hat{\mathrm{Y}}=1,519 \mathrm{X}
\end{aligned}
$$

Information:

$$
\begin{aligned}
& \hat{\mathrm{Y}}=\begin{array}{l}
\text { Student's mathematical connection } \\
\text { ability }
\end{array} \\
& \mathrm{X}=\underset{\text { Bprain-Based Learning }}{\text { approach }}
\end{aligned}
$$

From this equation it can be interpreted that the variable regression coefficient of the Brain-Based Learning (BBL) approach is 1.519; it means that if the Brain Based Learning (BBL) approach has increased by one time, then the students' mathematical connection ability $(\hat{Y})$ will increase by 1.519 .

To find out how much the contribution of the Brain-Based Learning (BBL) approach variable to the student's mathematical connection ability variable, it can be seen in Table 8 below

Tabel 7

Model Summary

\begin{tabular}{lllll}
\hline $\begin{array}{l}\text { Mode } \\
l\end{array}$ & $\mathrm{R}$ & $\mathrm{R}$ & $\begin{array}{l}\text { Adjuste } \\
\mathrm{d}\end{array}$ & $\mathrm{R}$ \\
& & $\begin{array}{l}\text { Std } \\
\text { Squar }\end{array}$ & $\begin{array}{l}\text { Error of } \\
\text { Square } \\
\text { Estimat } \\
\mathrm{e}\end{array}$ \\
\hline 1 & $\begin{array}{l}.633 \\
\mathrm{a}\end{array}$ & .400 & .375 & 10.910 \\
\hline
\end{tabular}

a. Predictor (Constant) Pendekatan BBL

b. Dependent Variable

Based on Table 8, the Adjusted R Square value is 0.375 . Furthermore, the coefficient of determination is tested using the formula:

$$
\begin{aligned}
& \mathrm{KP}=\mathrm{r} 2 \times 100 \% \\
& \mathrm{KP}=0.375 \times 100 \% \\
& \mathrm{KP}=37.5 \%
\end{aligned}
$$

From the results of these calculations, the coefficient of determination was $37.5 \%$. This means that the Brain Based Learning (BBL) approach variable contributes to improving students' mathematical connection skills by $37.5 \%$ and the remaining $62.5 \%$ is determined by other factors.

\section{Hypothesis testing}

Hypothesis testing is a test that aims to determine whether there is an effect of the application of the Brain-Based Learning (BBL) approach on students' mathematical connection abilities. Hypothesis testing in this study uses a simple regression test by looking at the $t$ value with the criteria for rejection or acceptance of the hypothesis as follows.

a. If the value of $t$ count $<\mathrm{t}$ table, then $\mathrm{H} 0$ is accepted

$b$. If the value of $t$ count $>t$ table, then $\mathrm{HO}$ is rejected

Based on Table 7 , the $t$ value is 4.003 with the $\mathrm{t}$ table value for $\mathrm{a}=0.05$ and $\mathrm{dk}=\mathrm{n}-2$, which is 1.710.This shows that the value of $\mathrm{t}$ count $>\mathrm{t}$ table is $4.003>1.710$, then $\mathrm{H} 0$ is rejected. and $\mathrm{Ha}$ accepted. So it can be concluded that there is an effect of the application of the Brain-Based Learning (BBL) approach on students' mathematical connection abilities

Based on the results of data analysis regarding student responses to the application of the BBL approach in mathematics learning, the minimum score was 61 and the maximum score was 82 , and the average score was 75.35. In the student response questionnaire, several components of the BBL approach are measured, namely pre-exposure, preparation, initiation and acquisition, elaboration, incubation and memory entry, 
verification, celebration, and integration, each of which has indicators.

Based on the study results, the average percentage of student responses from all indicators was $76 \%$, so it can be interpreted that the students' responses to the application of the BBL approach are in a strong category. The highest percentage of each student response indicator to applying the BBL approach lies in the 11th indicator, namely liking learning, with a percentage of $89 \%$.

As stated by Zarkasyi (2015: 61) that three main strategies can be developed in the BBL approach, namely: creating a learning environment that challenges students' thinking abilities, creating a pleasant learning environment, creating active and meaningful learning situations for students. Because learning by applying the BBL approach can create a pleasant learning environment, students also like the learning. It is in line with Nuraeni (2019) research, which obtained the highest average score, which lies in the indicator that students like and feel happy during the learning process.

Meanwhile, the lowest percentage of each student response indicator to the application of the BBL approach lies in the 8th indicator, which is having sufficient time to record material with a percentage of $67 \%$. This may be due to the short duration of the Teaching and Learning Activities (KBM).

After the researcher applied the BBL approach to the experimental class, then, the researcher tested the students' mathematical connection ability. The test results obtained a minimum value of 47.50 and a maximum value of 87.50 , and an average value of 68.5577 . The ability of students to connect mathematics is measured from the aspect of the connection between mathematical topics with indicators, namely using connections between mathematical topics (root numbers, ranks, and logarithms), aspects of connection with other disciplines with indicators, namely using connections between mathematics and other sciences (physics material displacement distances, resultant force), and aspects of connection with everyday life with indicators, namely using mathematics in solving problems related to everyday life.

Based on the study results, the average percentage of students' mathematical connection ability in using connections between mathematical topics, using connections between mathematics and other disciplines, and using mathematics in solving problems related to daily life, was $68 \%$. This can be interpreted that the mathematical connection ability after using the BBL approach on trigonometry is in a good category.

The highest percentage of each indicator of students' mathematical connection ability lies in the 3rd indicator, which is using mathematics to solve problems related to daily life, with a percentage of $69 \%$. There was no lowest percentage of the students' mathematical connection ability indicators in this study because the 1st and 2nd indicators obtained the same percentage of $68 \%$. This means that students' ability to connect between mathematical concepts and connecting mathematics with other disciplines is the same. Meanwhile, the ability of students to connect mathematics with everyday life is superior. This is in line with research conducted by Amin (2016), which revealed that the indicator of students 'mathematical connection ability is superior, namely connecting mathematics with everyday life with a large percentage of $98.92 \%$, which shows 
that students' ability to connect mathematics to life very good every day

\section{CONCLUSIONS AND IMPLICATIONS}

a. Conclusion

Based on the results of the research, data analysis, and discussion that has been carried out, namely regarding the effect of the application of the Brain-Based Learning (BBL) approach on the mathematical connection ability of students on trigonometric material, the following conclusions are obtained:

1. Student responses to the Brain-Based Learning (BBL) approach are in the strong category. This means that learning mathematics with the application of the Brain Based Learning (BBL) approach gets a positive response, the stages carried out in the BBL approach can be followed and accepted by students well.

2. Students' mathematical connection ability after applying the Brain-Based Learning (BBL) approach is in a good category. This means that students can connect the topics of mathematics, mathematics with other fields of science, and mathematics with everyday life in trigonometric material well supported by the BBL approach in the learning process.

b. Implication

The suggestions that the researcher wants to convey after conducting this research are as follows:

\section{For Students.}

Students should further improve their mathematical connection skills and not quickly forget the teacher's subject matter because it will be useful for learning the further subject matter.
2. For Teachers.

Teachers should understand the importance of mathematical connections for students because mathematical connections are one of the basic abilities students must have in learning mathematics. The Brain-Based Learning (BBL) approach can be used as an innovation and alternative learning to implement mathematics learning.

\section{For Schools.}

The school is expected to start encouraging teachers to use innovative, creative, and fun learning approaches such as the BrainBased Learning (BBL) approach in mathematics and other fields of study to make the learning process more meaningful. Also, more attention is paid to the completeness of the facilities and infrastructure to support learning.

\section{REFERENCES}

Al'Azzy, U. L., \& Budiono, E. (2008). Penerapan Strategi Brain Based Learning yang dapat Meningkatkan Keterampilan Berpikir Tingkat Tinggi. http://library.um.ac.id/ptk/index.php $? \bmod =$ detail \&id= $=59192$

Anthony, G., \& Walshaw, M. (2009). Characteristics of effective teaching of mathematics: A view from the West. Journal of Mathematics Education, 2(2), 147-164.

Anandita, G. P. (2015). Analisis Kemampuan Koneksi Matematis Siswa SMP Kelas VIII pada Materi Kubus dan Balok (Doctoral dissertation, Universitas Negeri Semarang). http://lib.unnes.ac.id/21529/

Baskoro, E. P., \& Wihaskoro, A. M. (2014). Evaluasi Pembelajaran.Cirebon: Nurjati Press 
Hendriana, H., \& Soemarmo, U. (2014). Penilaian Pembelajaran Matematika. PT. Refika Aditama.

Hidayah, L. (2015). Efektivitas model pembelajaran Brain Based Learning (BBL) dengan pendekatan saintifik berbantu alat peraga sederhana terhadap hasil belajar Matematika peserta didik kelas VIII pada materi garis singgung lingkaran di MTs Darul Ulum tahun pelajaran 2014/2015 (Doctoral dissertation, UIN Walisongo). http://eprints.walisongo.ac.id/5104/

House, P. A., \& Coxford, A. F. (1995). Connecting Mathematics across the Curriculum. 1995 Yearbook. National Council of Teachers of Mathematics, 1906 Association Drive, Reston, VA 22091-1593. https://eric.ed.gov/?id=ED384524

Istianah, E. (2013). Meningkatkan Kemampuan Berpikir Kritis Dan Kreatif Matematik dengan Pendekatan Model Eliciting Activities (MEAs) pada siswa. Jurnal Pengajaran MIPA, 2(1), 51-62. https://doi.org/https://doi.org/10.2246 0/infinity.v2i1.p43-54

Jamal, F. (2019). Analisis kesulitan belajar siswa dalam mata pelajaran matematika pada materi peluang kelas XI IPA SMA Muhammadiyah Meulaboh Johan Pahlawan. MAJU: Jurnal Ilmiah Pendidikan Matematika, 1(1), 18-36 https://ejournal.stkipbbm.ac.id/index $. \mathrm{ph} \mathrm{p} / \mathrm{mtk} / \mathrm{article} / \mathrm{view} / 232$

Jensen, E. (2008). Brain Based Learning (Pembelajaran Berbasis Kemampuan Otak : Cara baru dalam Pengajaran dan Pelatihan). Pustaka Pelajar.

Lestari, K. E. (2014). Implementasi BrainBased Learning untuk meningkatkan kemampuan koneksi dan kemampuan berpikir kritis serta motivasi belajar siswa SMP. Judika (Jurnal pendidikan UNSIKA), 2(1), 36-46.

https://journal.unsika.ac.id/index.ph p/judika/article/view/120

Linto, R. L., Elniati, S., \& Rizal, Y. (2012). Kemampuan koneksi matematis dan metode pembelajaran quantum teaching dengan peta pikiran. 1(1), 83-87.

https://ejournal.unsri.ac.id/index.php ljpm

Nasehuddien, T. S., \& Manfaat, B. (2015). Dasar-Dasar Metodologi Penelitian. Cirebon: Nurjati Press.

Nuraeni, F. (2019). Penggunaan Media Still Picture Dalam Pembelajaran Menulis Puisi Berorientasi Pada Unsur Batin Dan Unsur Fisik Kelas $\mathrm{X}$ Sma Pasundan 2 Bandung Tahun Pelajaran 2018/2019 (Doctoral dissertation, FKIP UNPAS). http://repository.unpas.ac.id/43219/

Rizka, S., \& Mastur, Z. (2014). Model Project Based Learning Bermuatan Etnomatematika Untuk Meningkatkan Kemampuan Koneksi Matematika. Unnes Journal of Mathematics Education Research, 3(2). $72-78$. https://journal.unnes.ac.id/sju/index. php/ujmer/article/view/4621

Romberg, T. A. (2016). Fosters Mathematical Thinking and Problem Solving: Connections Between Theory. Mathematical Thinking and Problem Solving.

Saragih, A. H. (2008). Kompetensi Minimal Seorang Guru Dalam Mengajar. Jurnal Tabularasa, 5(1), 23-34. https://doi.org/http://digilib.unimed.a c.id/id/eprint/715

Siregar, S. (2010). Statistika deskriptif untuk penelitian. Jakarta: Rajawali Pers. 
Sugiyono. (2013). Metode Penelitian Kombinasi. Bandung: Alfabeta.

Supriadie, D., \& Darmawan, D. (2012). Komunikasi Pembelajaran. PT. Remaja Rosdakarya.
Yulvinamaesari, Y. (2014). Implementasi Brain Based Learning dalam Pembelajaran Berbasis Pendidikan Karakter. Prosiding, 1(1), 99-106. http://journal.uncp.ac.id/index.php/p roceding/article/view/229 